\title{
Emerging targeted drug therapies in skeletal dysplasias
}

Patrick Yap ${ }^{1}$, and Ravi Savarirayan ${ }^{1,2^{*}}$

${ }^{1}$ Victorian Clinical Genetics Services, Murdoch Children's Research Institute, Melbourne, Australia.

${ }^{2}$ Department of Paediatrics, University of Melbourne, Melbourne, Australia.

*Correspondence to: Professor Ravi Savarirayan, Victorian Clinical Genetics Services, Level 4, Murdoch Children's Research Institute, Parkville, Victoria, Australia 3052.

Tel.: +613 83416244, Fax: +613 83416390, Email: ravi.savarirayan@vcgs.org.au

Running heads: Yap and Savarirayan, skeletal dysplasia therapy

Funding sources: None

Conflict of interest: Patrick Yap and Ravi Savarirayan are a sub-investigator and principal investigator, respectively, for Biomarin Pharmaceutical BMN111 (vosoritide) clinical trial.

ABSTRACT

Quantum advances have occurred in the field of human genetics in the six decades since Watson and Crick expressed their "wish to suggest a structure for the salt of deoxyribose nucleic acid". These culminated with the human genome project, which has opened up myriad possibilities, including that of individualized genetic medicine, the ability to deliver medical advice, management, and therapy tailored to an individual's genetic blueprint. Advances in genetic diagnostic capabilities have been rapid, to the point where the genome can be sequenced for several thousand dollars. Crucially, it has facilitated the identification of targets for "precision" treatments to combat genetic diseases at their source. This manuscript will review 
the innovative, pathogenesis-based therapies that are revolutionizing management of skeletal dysplasias, giving patients and families new options and outcomes.

Key words: skeletal dysplasia, pharmacologic therapy, targeted treatment.

\section{INTRODUCTION}

The inherited disorders of the skeleton (skeletal dysplasias) are individually rare but collectively common conditions caused by abnormal development, growth and maintenance of the human skeleton [Krakow et al., 2010]. To date, medical and surgical management of these disorders has been symptomatic due to lack of pathogenesis-based treatments. Over the past three years, disruptive innovations in the form of targeted therapies have emerged that are dramatically changing the natural history of these conditions. This review will focus on the most promising of these therapies in clinical practice, and touch upon possible future therapeutic options for skeletal dysplasias.

\section{Achondroplasia}

Achondroplasia (OMIM 100800) is the most common form of human dwarfism, with an estimated prevalence of 4-6 per 100,000 [Ireland et al., 2014]. It is caused by a gain-of-function mutation in the fibroblast growth factor receptor 3 (FGFR3) gene resulting in abnormal endochondral ossification. Almost all individuals affected by achondroplasia harbor a c.1138G >A (p.G380R) or c.1138G >C (p.G380R) mutation in the transmembrane domain. FGFR3 consists of extracellular (ligand-binding), transmembrane and intracellular (kinase) components, linked intricately to the signaling pathways involving signal transducer and activator of transcription (STAT) 
and mitogen-activated protein kinase (MAPK) (Figure 1). Activation of FGFR3 has an inhibitory effect on the proliferation and terminal differentiation of growth plate chondrocytes, and synthesis of extracellular matrix [Hart et al., 2000; Choi et al., 2001; Murakami et al., 2004]. The negative regulatory role of FGFR3 is essential for physiological longitudinal bone growth by slowing the rate of cartilage template formation and turnover during the growth phase [Horton and Degnin, 2009; Ornitz, 2005].

Advancements in understanding the pathophysiology of achondroplasia have prompted efforts in treatment strategies targeting the FGFR3-mediated signaling pathway. Early pharmacologic therapies were based on the principles of successful oncology treatment, using kinase inhibitor and antibody blockade, modified to selectively target FGFR3 and its activation [Aviezer et al., 2003; Rauchenberger et al., 2003]. Although, these therapies were shown to have positive effects on bone growth in vitro, the results have not been replicated in vivo.

Second generation pharmacologic therapies appeared more promising with amelioration of the skeletal phenotype, at least in the murine models. They comprise of strategies that interfere with the binding of FGFR3 to its ligands and blockade of MAPK signaling pathway. P3 is a 12-amino acid peptide designed to target extracellular component of FGFR3 with high affinity. The binding of P3 to FGFR3 interferes with ligand binding, inhibiting receptor activation and subsequent signallng pathways [Jin et al., 2012]. A decoy receptor in the form of soluble FGFR3 isoform competes with physiologic ligands to reduce FGFR3 signaling. The isoform lacks the trans-membrane component rendering it impotent in signal transmission [Garcia et al., 2013]. 
Meclozine is an antihistamine commonly used as antiemetic. It promotes longitudinal bone growth by a mechanism that is not fully delineated, but possibly by blocking downstream FGFR3 signaling pathway at the MEK-ERK level [Matsushita et al., 2013; Matsushita et al., 2015]. Statins have been shown to promote significant bone growth in one study involving three patients. Yamashita et al. [2014] used induced pluripotent stem cells derived from the fibroblast cells of patients with thanatophoric dysplasia type 1 (TD1) and achondroplasia to investigate the effect of statins as treatment. The authors proposed statin decreases the signaling life span of mutant FGFR3 receptors, therefore ameliorating the skeletal phenotype of these conditions [Yamashita et al., 2014].

C-natriuretic peptide (CNP) and its receptor, natriuretic peptide receptor-B (NPR-B) play major regulatory roles in endochondral ossification and longitudinal bone growth [Yasoda et al., 1998; Miyazawa et al., 2002]. Both molecules are expressed in the proliferative and terminal differentiation zones of the growth plates [Yasoda et al., 1998]. Interaction between CNP and NPR-B causes accumulation of intracellular cGMP, resulting in increased downstream NPR-B signaling, which intersects with the FGFR3 downstream signaling at the RAF level within the MAPK pathway (Figure 1). CNP/NPR-B activation downregulates the inhibitory effects of FGFR3 signal [Miyazawa et al., 2002; Krejci et al., 2005]. The delicate regulation between the FGFR3 and CNP systems are essential for endochondral ossification and longitudinal bone growth.

NPR-B has been implicated in the pathogenesis of rare phenotypes involving longitudinal bone growth or height, exemplified by conditions such as acromesomelic dysplasia, Maroteaux type (OMIM 602875) and NPR-B-associated 
short stature, caused by homozygous or compound heterozygous and heterozygous inactivating mutations in NPR-B, respectively. [Bartels et al., 2004; Vasques et al., 2013; Amano et al., 2014] NPR-B gain-of-function mutations have been associated with bone overgrowth and tall stature [Miura et al., 2012; Hannema et al., 2014; Miura et al., 2014].

The discovery and understanding of physiological functions of CNP and NPR-B in promoting longitudinal bone growth have opened avenues for a targeted therapeutic strategy in achondroplasia. Researchers have demonstrated that CNP knockout mice developed severe growth deficiency, with restoration of normal growth when these mice were crossed with transgenic mice overexpressing CNP in cartilage [Suda et al., 1998; Chusho et al., 2001]. The skeletal phenotype was ameliorated when mice with achondroplasia were crossed with CNP overexpressing transgenic mice [Yasoda et al., 2004; Naski et al., 1998]. These findings formed the basis for human clinical studies.

The CNP analogue, named vosoritide by the World Health Organization has an extended half-life attributed to its resistance to neutral endopeptidase. Vosoritide administered subcutaneously once daily was shown to stimulate bone growth in murine models [Suda et al., 1998; Wendt et al., 2015]. Vosoritide is the only targeted pharmacologic therapy for achondroplasia that has proceeded to human clinical trial. The results from the Phase 1 trial showed that vosoritide is generally well tolerated with no dose-limiting, clinically significant toxicities in healthy adult males. The phase 2 trial was an open-label, sequential cohort doseescalation study involving children aged 5-14 years with a molecularly confirmed diagnosis of achondroplasia. Patients were randomized for one of three doses (2.5, 
7.5 or 15 microgram/kilogram) of vosoritide, given as daily subcutaneous injection for 6 months (see ClinicalTrials.gov). Data from these studies showed favorable safety profile and efficacy at higher dosage, with a $50 \%$ increase in growth velocity over individual baseline in the $15 \mathrm{mcg} / \mathrm{kg}$ cohort. The trial has now proceeded to an 18-month extension study. All participating patients have been switched to $15 \mathrm{mcg} / \mathrm{kg}$ dose for duration of 18 months.

Klag and Horten [2015] discussed the challenges faced in the development of targeted therapies for achondroplasia, in particularly the delivery of potential therapeutic agents to the avascular growth plates. The advancement of gene therapy in other condition such as osteoarthritis may shed light in overcoming such obstacles.

\section{Osteogenesis imperfecta}

Osteogenesis imperfecta $(\mathrm{OI})$ is associated with bone fragility and fractures. The prevalence of OI is approximately 5-10 in 100,000 [Monti et al., 2010]. The phenotype commonly associated with OI includes osteoporosis with increased tendency for fractures, skeletal deformity, scoliosis, and joint laxity. Extra-skeletal features encompass hearing impairment, abnormal dentition, sclera discoloration, hypercalciuria, aortic root dilatation and neurologic manifestations, including hydrocephalus and basilar invagination [Harrington et al., 2014; Shaker et al., 2015]. Most features of Ol can have variable severity, ranging from adult-onset aches, pains and fractures to early perinatal lethality. Common medical complaints of affected individuals in mild to moderate Ol are fractures and pain.

Ninety percent of OI cases are caused by heterozygous mutations in COL1A1 and COL1A2 [Lindahl et al., 2014]. These genes are important for the production of 
type 1 collagen, which is the most abundant type of connective tissue that constitutes the bone and skin. Mutations impair the gene function resulting in a qualitative and quantitative reduction in type 1 collagen [Shaker et al., 2015; Lindahl et al., 2014]. The remaining proportions of OI are inherited in an autosomal recessive manner, and PLS3 (plastin 3) has been implicated in X-linked osteoporosis [van Djik et al., 2013; Laine et al., 2015].

Rarer molecular causes for OI have emerged, involving genes that code for modification enzymes, chaperone proteins and signaling proteins essential for production of type 1 collagen. [Shaker et al., 2015] The discovery of additional Olassociated genes provides explanation for the wide phenotypic spectrum of this entity. Management of OI involves a multidisciplinary approach including rehabilitation, surgical and pharmacologic intervention, aiming to maximize mobility and daily competencies, and decrease bone fragility and pain [Harrington et al., 2015].

The most studied and widely used pharmacologic treatment for $\mathrm{Ol}$ is bisphosphonate, a synthetic pyrophosphate analogue with long skeletal half-life that binds to hydroxyapatite crystals in mineralized bone. Bisphosphonates reduce the number of osteoclasts and antagonize osteoclastic activity resulting in diminished bone resorption [Reyes et al., 2016].

Bisphosphonates are used in the treatment of moderate to severe Ol in children. The superiority of bisphosphonates in increasing bone mineral density (BMD) was consistently demonstrated in controlled and observational studies, with most gain in the first 3-4 years of treatment [Rauch et al., 2003]. Benefits of bisphosphonates documented in observational trials include decreased fractures and 
bone pain, improved vertebral shape, strength and improved activities of daily living. [Glorieux et al., 1998; Land et al., 2006; Lowing et al., 2007]. These results were not consistently replicated in randomized controlled trials. Intravenous bisphosphonates were shown to reduce peripheral fracture rates, increase vertebral height and mineral density but showed no difference in decreasing pain when compared to no treatment [Letocha et al., 2005; Gatti et al., 2005]. Palomo et al. [2015] reviewed the outcome of long-term (10-year) intravenous bisphosphonates therapy, and concluded that this therapy was associated with higher Z-scores for BMD in the lumbar spine and improvement of vertebral shape. The long-bone fracture rates remain high and the majority of patients developed scoliosis.

Two studies on oral bisphosphonates as treatment for Ol by Seikaly et al. [2005] and Bishop et al. [2013] demonstrated reduction in fractures and bone pain, respectively. Meta-analysis of bisphosphonates' role in preventing fractures in OI was inconclusive [Hald et al., 2015].

There is currently no consensus on the optimal bisphosphonate dosing and duration of treatment. The well-recognized side effects of bisphosphonates are atypical femur fractures, most likely secondary to impaired bone resorption, and osteonecrosis of the jaw. The latter side effect has not been observed in the pediatric group. Other potential extra-skeletal effects include gastrointestinal symptoms, atrial fibrillation and increased risk for esophageal tumor [Reyes et al., 2016]. Flu-like symptoms and transient hypocalcemia are common especially after the first dose [Munns et al., 2004], but may be reduced with antihistamine coverage. Other pharmacologic therapies trialed in OI include anabolic agents that stimulate bone growth, such as growth hormone and teriparatide (PTH 1-34), a 
recombinant parathyroid hormone. Growth hormone was shown in one study to increase BMD and growth velocity when use in conjunction with bisphosphonates [Antoniazzi et al., 2010]. Teriparatide was trialed in a study involving adults with OI and shown to increase BMD and vertebral strength but only in the mild form of OI [Orwoll et al., 2014].

Receptor activator of nuclear factor (NF-kappa $\beta$ ) ligand (RANKL), its cellular receptor, receptor activator of NF-kappa $\beta$ (RANK), and the decoy receptor osteoprotegerin (OPG) constitute a cytokine system that is essential for bone resorption. RANKL produced by osteoblastic cells, plays a crucial role in osteoclast formation, fusion, activation, and survival [Hofbauer et al., 2001]. Denosumab is a monoclonal antibody that binds RANKL and disrupts bone resorption. Hoyer-Kunh et al. [2014] published results of the use of Denosumab in four pediatric patients with Ol type IV, showing increased BMD with reduced fracture rate, normalization of vertebral shape and increased mobility. They also published data of Denosumab use on two patients with OI and known COL1A1/COL1A2 mutations. Denosumab effectively increased BMD and has long lasting effect in promoting bone growth [Hoyer-Kunh et al., 2014].

Shaker et al. [2015] summarized future pharmacologic agents in the treatment of $\mathrm{Ol}$, including anti-sclerostin and anti-transforming growth factor- $\beta$ (TGF- $\beta$ ) antibodies that disrupt the LRP5/WnT and TGF- $\beta$ signaling pathways, respectively to increase bone formation and decrease bone resorption. These antibodies were shown to rescue the skeletal phenotype of CRTAP-related autosomal recessive OI in mice [Grafe et al., 2015; Grafe et al., 2014]. Gene therapy with allele silencing and cell-based therapy involving bone marrow and 
mesenchymal cell transplantation have rapidly attracted attention in the research of OI treatment, and may prove useful future therapeutic options. (Table I)

\section{Hypophosphatasia}

Hypophosphatasia (HPP) is caused by a deficiency in tissue-nonspecific alkaline phosphatase (TNSALP) due to mutations in the ALPL gene. The condition is characterized by mineralization defects of the bones and teeth causing osteomalacia, increased risk of fracture, bone pain, and loss of dentition. Extraskeletal manifestations involving the central nervous, respiratory and renal systems are common in the severe form of this widely variable condition [Mornet, 2007]. HPP is clinically heterogeneous and classified according to the age of onset and phenotypic severity [Mornet, 2007; Whyte, 2010]. In general, the childhood and adult forms have a milder phenotype that may present with only premature loss of dentition (odontohypophosphatasia). The infantile and perinatal forms (OMIM 241500) are at the severe end of the spectrum. Affected individuals rarely survive beyond infancy without intervention, mainly secondary to respiratory failure and seizures [Whyte, 2010; Nakamura-Utsunomiya et al., 2010]. The estimated prevalence of severe HPP is 0.3-1 in 100,000 [Fraser, 1957; Mornet et al., 2011.

The TNSALP protein converts inorganic pyrophosphate (PPi) to phosphate ( $\mathrm{Pi}$ ) by hydrolysis. Pi is essential for hydroxyapatite formation, whereas PPi inhibits the process. The lack of TNSALP leads to accumulation of PPi and antagonization of the bone mineralization process [Harmey et al., 2004; Orimo, 2010] (Figure 2). Enzyme replacement therapy using exogenous TNSALP was effective in rescuing the lifethreatening skeletal and functional phenotype in mice with severe HPP [Waymire et al., 1995; Narisawa et al, 1997]. These findings led to clinical trials in treating severe 
forms of HPP in human using recombinant TNSALP, now known as asfotase alfa.

Whyte et al. [2012], in a clinical trial involving 10 patients with lifethreatening HPP published the promising primary results of asfotase alfa. The therapy effectively improved bone mineral density, fracture healing and radiological features, increased membranous bone formation and decreased deformities. Improved pulmonary function, growth and reduction in plasma PPi and pyridoxal 5' phosphate were also reported. The agent was well tolerated with no significant drug-related adverse events. Three-year follow-up showed a survival rate of $90 \%$ [Whyte et al., 2014], a life-changing improvement. These results were supported by other similar clinical trials by Madson et al. [2014] and Rockmann-Greenberg et al. [2014] in terms of clinical safety and effectiveness. Reports of similar clinical trials in adolescent and adult cohorts are scarce. Kishnani et al. [2012] reported asfotase alfa decreased TNSALP substrate accumulation and improved functional outcome in one adult cohort. Efforts to ensure targeted delivery of therapy agents to the skeletal system have been attempted with promising results both in mice and human clinical trials. [Whyte et al., 2012; Nishioka et al., 2006; Millán et al., 2008]. These approaches optimize drug deliverance to targeted tissue and minimize the potential side effects of therapy. Asfotase alfa (STRINSIQ ${ }^{\mathrm{TM}}$ ) is now an FDA-approved drug, and commercially available treatment option for HPP.

On a research level, gene therapy in murine models of HPP involving transuterine, intraperitoneal injection of adeno-associated viral (AAV) expressing bonetargeted TNSALP appeared promising [Sugano et al., 2012]. These authors documented that HPP murine fetuses that mimic the severe infantile phenotype were rescued by fetal gene therapy from early gestation, evident postnatally by 
normal bone mineralization, good weight gain and seizure-free survival until age 8 weeks. The authors proposed gene therapy as potential in utero therapy following antenatal diagnosis.

Other emerging skeletal dysplasia therapies

Fibrodysplasia ossificans progressiva (FOP) (OMIM 135100) and Morquio syndrome (Mucopolysaccharidosis type IVa) (OMIM 253000) are debilitating and potentially life-threatening skeletal dysplasias with unmet needs in terms of targeted therapies. The prevalence of FOP and Morquio syndrome is 1 in 1,000,000 and 0.2-0.6 in 100,000, respectively [Pignolo et al., 2011; Leadley et al., 2014]. The genetic and disease mechanisms of these conditions are well researched and documented. [Pignolo et al., 2011; Shore et al., 2006; Tomatsu et al., 2014]. Most pharmacologic therapies for FOP and Morquio syndrome aim at preventing the progression of disease and associated complications.

Corticosteroids and retinoic acid were tested in patients with FOP in the late 1990s. The effectiveness of these agents in inhibiting heterotopic ossification was inconclusive from the studies [Brantus and Meunier, 1998; Chakkalakal et al., 2016]. The use of palovarotene, a retinoic acid receptor gamma (RARY) agonist effectively inhibited spontaneous and injury-induced ectopic chondrogenesis and osteogenesis in murine models, as well as restoring and maintaining bone growth and musculoskeletal functions [Chakkalakal et al., 2016]. A clinical trial using palovarotene is now in Phase 2 studies. Sinha et al. [2016] documented that corticosteroids and palovarotene act on distinct pathways, and share several common steps and phases in inhibiting chondrogenesis and osteogenesis with no significant interference between the agents. These authors have proposed the 
potential benefits of combined therapy.

Tomatsu et al. [2014] reviewed treatments available for Morquio syndrome, and most only partially improve the clinically phenotype. In particular, the skeletal phenotype is irreversible. Elosulfase alfa (VIMIZIM ${ }^{\oplus}$ ) is a recombinant human $\mathrm{N}$ acetylgalactosamine-6-sulfate sulfatase (GALNS), an FDA-approved drug available for treatment of Morquio syndrome. A 24-week, randomized, double-blind, placebocontrolled phase 3 trial demonstrated that elosulfase alfa was clinically well tolerated and safe, with statistically significant improvement in a primary efficacy measurement of endurance (distance of 6-minute walk) and reduction in urinary keratan sulphate, the main contributory factor to the pathogenesis of disease manifestations. Elosulfase alfa also reported to improve respiratory function, growth in height and activities of daily living [Hendriksz et al., 2014; Hendriksz et al., 2015]. The potential of cell-based therapy

Successful intervention with bone marrow transplantation in cases of severe infantile HPP has been reported in two patients; both developed sustained bone mineralization and clinical improvement [Whyte et al., 2003; Cahill et al., 2007]. Three other infants with severe HPP have been treated with bone marrow and mesenchymal stem cell transplantation [Tadokoro et al., 2009; Taketani et al., 2014]. The interventions yielded promising results with sustained improvement on skeletal phenotype and functional outcome at the time of reporting. Such methods are not without side effects, evident by development of Philadelphia-positive acute lymphoblastic leukemia in one of the infants, presumably attributed to the pretransplant immunosuppressive therapy [Taketani et al., 2013]. The infant was reported to have achieved complete histological and molecular remission following a 
second transplantation.

The mortality rate of malignant infantile osteopetrosis (OMIM 259700) is approximately $70 \%$ by 6 years of age in untreated patients [Orchard et al., 2015]. Hematopoietic stem cell transplant (HSCT) offers a cure to malignant infantile osteopetrosis, and is most effective when performed early. The most common cause of death in the first year post-transplant is graft failure, and pre-transplant conditioning carries a high risk of adverse outcomes [Orchard et al., 2015]. Natsheh et al. [2016] reported that fludarabine-based pre-transplant conditioning improved morbidity and mortality related to HSCT. The long-term (10-year) survival rate was higher among the HLA-matched sibling compared to alternative donor transplants (62\% vs. 39\%) [Orchard et al., 2015. An HLA-matched sibling donor HSCT is the standard of care, but not feasible for the majority of patients. Disease-specific pharmacologic therapy is not yet available for malignant infantile osteopetrosis, although early clinical trials of interferon gamma are planned (ClinicalTrials.gov Identifier: NCT02666768).

The new era of genomic technology and understanding has brought with it the tantalizing possibility of treatment for genetic diseases. Skeletal dysplasias serve as a model for this brave new paradigm with several treatments already in clinical use, and many others working their way through the clinical trial pipeline. These pathogenesis-based therapies promise to be disease modifying and, in some cases, life changing for individuals affected by these conditions and provides families with new options and hope. The challenges for the future will be to determine the optimal therapy, timing, and dosage for each patient and condition (individualized medicine). In addition, as these therapies modify the native phenotypes and natural 
history of skeletal dysplasias, new management challenges will need to be identified, tools developed to measure quantitative and qualitative improvements in function and quality of life, and updated counseling provided to patients and their families.

\section{ACKNOWLEDGEMENTS}

The authors dedicate this manuscript to Dr. John Carey, caring physician, curious researcher, and friend. This manuscript is a retrospective literature review therefore did not require approval from our institution's ethics committee.

\section{INTERNET RESOURCES}

Clinical Trials.Gov. 2015. A service of the U.S. National Institutes of Health. A Phase 2 Study of BMN-111 to Evaluate Safety, Tolerability And Efficacy in Children With Achondroplasia $(\mathrm{ACH})$.

https://clinicaltrials.gov/ct2/show/NCT02055157?term=achondroplasia\&rank=3.

\section{References}

Amano N, Mukai T, Ito Y, Narumi S, Tanaka T, Yokoya S, Ogata T, Hasegawa T. 2014. Identification and functional characterization of two novel NPR2 mutations in Japanese patients with short stature. J Clin Endocrinol Metab 99:713-718.

Antoniazzi F, Monti E, Venturi G, Franceschi R, Doro F, Gatti D, Zamboni G, Tatò L. 2010. GH in combination with bisphosphonate treatment in osteogenesis imperfecta. Eur J Endocrinol 163(3):479-487.

Aviezer D, Golembo M and Yayon A. 2003. Fibroblast growth factor receptor-3 as a therapeutic target for Achondroplasia-genetic short limbed dwarfism. Curr Drug Targets 4:353-365.

Bartels CF, Bukulmez H, Padayatti P, Rhee DK, van Ravenswaaij-Arts C, Pauli RM, 
Mundlos S, Chitayat D, Shih LY, Al-Gazali LI, Kant S, Cole T, Morton J, Cormier-

Daire V, Faivre L, Lees M, Kirk J, Mortier GR, Leroy J, Zabel B, Kim CA, Crow Y, Braverman NE, van den Akker F, Warman ML. 2004. Mutations in the transmembrane natriuretic peptidereceptor NPR-B impair skeletal growth and cause acromesomelic dysplasia, type Maroteaux. Am J Hum Genet 75:27-34.

Bishop N, Adami S, Ahmed SF, Antón J, Arundel P, Burren CP, Devogelaer JP, Hangartner T, Hosszú E, Lane JM, Lorenc R, Mäkitie O, Munns CF, Paredes A, Pavlov H, Plotkin H, Raggio CL, Reyes ML, Schoenau E, Semler O, Sillence DO, Steiner RD. 2013. Risedronate in children with osteogenesis imperfecta: a randomised, double-blind, placebo-controlled trial. Lancet 382(9902):14241432.

Brantus JF, Meunier PJ. 1998. Effects of intravenous etidronate and oral corticosteroids in fibrodysplasia ossificans progressiva. Clin Orthop 346:117-120.

Cahill RA, Wenkert D, Perlman SA, Steele A, Coburn SP, McAlister WH, Mumm S, Whyte MP. 2007. Infantile hypophosphatasia: transplantation therapy trial using bone fragments and cultured osteoblasts. J Clin Endocrinol Metab 92:2923-2930. Chakkalakal SA, Uchibe K, Convente MR, Zhang D, Economides AN, Kaplan FS, Pacifici M, Iwamoto M, Shore EM. Palovarotene Inhibits Heterotopic Ossification and Maintains Limb Mobility and Growth in Mice with the Human ACVR1 R206H Fibrodysplasia Ossificans Progressiva (FOP) Mutation. J Bone Miner Res. In Press. Choi DY, Toledo-Aral JJ, Lin HY, Ischenko I, Medina L, Safo P, Mandel G, Levinson SR, Halegoua S, Hayman MJ. 2001. Fibroblast growth factor receptor 3 induces gene expression primarily through Ras-independent signal transduction pathways. J Biol Chem 276:5116-5122. 
Chusho H1, Tamura N, Ogawa Y, Yasoda A, Suda M, Miyazawa T, Nakamura K, Nakao

K, Kurihara T, Komatsu Y, Itoh H, Tanaka K, Saito Y, Katsuki M, Nakao K. 2001.

Dwarfism and early death in mice lacking C-type natriuretic peptide. Proc. Natl Acad Sci USA 98:4016-4021.

Fraser D. 1957. Hypophosphatasia. Am J Med 22:730-746.

Garcia S, Dirat B, Tognacci T, Rochet N, Mouska X, Bonnafous S, Patouraux S, Tran A, Gual P, Le Marchand-Brustel Y, Gennero I, Gouze E. 2013. Postnatal soluble FGFR3 therapy rescues achondroplasia symptoms and restores bone growth in mice. Sci Transl Med 5:203ra124.

Gatti D, Antoniazzi F, Prizzi R, Braga V, Rossini M, Tatò L, Viapiana O, Adami S. 2005. Intravenous neridronate in children with osteogenesis imperfecta: a randomized controlled study. J Bone Miner Res 20:758-763.

Glorieux FH, Bishop NJ, Plotkin H, Chabot G, Lanoue G, Travers R. 1998. Cyclic administration of pamidronate in children with severe osteogenesis imperfecta. N Engl J Med 339:947-952.

Grafe I, Alexander S, Yang T, Lietman C, Homan EP, Munivez E, Chen Y, Jiang MM, Bertin T, Dawson B, Asuncion F, Ke HZ, Ominsky MS, Lee B. Sclerostin Antibody Treatment Improves the Bone Phenotype of Crtap-/- Mice, a Model of Recessive Osteogenesis Imperfecta. J Bone Miner Res. In Press.

Grafe I, Yang T, Alexander S, Homan EP, Lietman C, Jiang MM, Bertin T, Munivez E, Chen Y, Dawson B, Ishikawa Y, Weis MA, Sampath TK, Ambrose C, Eyre D, Bächinger HP, Lee B. 2014. Excessive transforming growth factor- $\beta$ signaling is a common mechanism in osteogenesis imperfecta. Nat Med 20:670-675. Hald JD, Evangelou E, Langdahl BL, Ralston SH. 2015. Bisphosphonates for the 
prevention of fractures in osteogenesis imperfecta: meta-analysis of placebocontrolled trials. J Bone Miner Res 30:929-933.

Hannema SE, van Duyvenvoorde HA, Premsler T, Yang RB, Mueller TD, Gassner B, Oberwinkler H, Roelfsema F, Santen GW, Prickett T, Kant SG, Verkerk AJ, Uitterlinden AG, Espiner E, Ruivenkamp CA, Oostdijk W, Pereira AM, Losekoot M, Kuhn M, Wit JM. 2013. An activating mutation in the kinase homology domain of the natriuretic peptide receptor-2 causes extremely tall stature without skeletal deformities. J Clin Endocrinol Metab 98:E1988-E1998.

Harmey D, Hessle L, Narisawa S, Johnson KA, Terkeltaub R, Millan JL. 2004.

Concerted regulation of inorganic pyrophosphate and osteopontin by akp2, enpp1, and ank: an integrated model of the pathogenesis of mineralization disorders. Am J Pathol 164:1199-1209.

Harrington J, Sochett E, Howard A. 2014. Update on the Evaluation and Treatment of Osteogenesis Imperfecta. Pediatr Clin N Am 61:1243-1257.

Hart KC, Robertson SC, Kanemitsu MY, Meyer AN, Tynan JA, Donoghue DJ. 2000. Transformation and Stat activation by derivatives of FGFR1, FGFR3, and FGFR4. Oncogene 19:3309-3320.

Hendriksz CJ, Burton B, Fleming TR, Harmatz P, Hughes D, Jones SA, Lin SP, Mengel E, Scarpa M, Valayannopoulos V, Giugliani R; STRIVE Investigators, Slasor P, Lounsbury D, Dummer W. 2014. Efficacy and safety of enzyme replacement therapy with BMN 110 (elosulfase alfa) for Morquio A syndrome (mucopolysaccharidosis IVA): a phase 3 randomised placebo-controlled study. J Inherit Metab Dis 37:979-990.

Hendriksz CJ, Giugliani R, Harmatz P, Mengel E, Guffon N, Valayannopoulos V, Parini 
R, Hughes D, Pastores GM, Lau HA, Al-Sayed MD, Raiman J; STRIVE Investigators, Yang K, Mealiffe M, Haller C. 2015. Multi-domain impact of elosufase alfa in Morquio A syndrome in the pivotal phase III trial. Mol Genet Metab 114:178-185. Hofbauer LC, Heufelder AE. 2001. Role of receptor activator of nuclear factor kappaB ligand and osteoprotegerin in bone cell biology. J Mol Med (Berl). 79:243-253. Horton WA and Degnin CR. 2009. FGFs in endochondral skeletal development. Trends Endocrinol Metab 20:341-348.

Hoyer-Kuhn H, Netzer C, Koerber F, Schoenau E, Semler O. 2014. Two years' experience with denosumab for children with osteogenesis imperfecta type VI. Orphanet J Rare Dis 9:145.

Hoyer-Kuhn H, Semler O, Schoenau E. 2014. Effect of denosumab on the growing skeleton in osteogenesis imperfecta. J Clin Endocrinol Metab 99:3954-3955. Ireland PJ, Pacey V, Zankl A, Edwards P, Johnston LM, Savarirayan R. 2014. Optimal management of complications associated with achondroplasia. Appl Clin Genet 7:117-125.

Jin M, Yu Y, Qi H, Xie Y, Su N, Wang X, Tan Q, Luo F, Zhu Y, Wang Q, Du X, Xian CJ, Liu P, Huang H, Shen Y, Deng CX, Chen D, Chen L. 2012. A novel FGFR3-binding peptide inhibits FGFR3 signaling and reverses the lethal phenotype of mice mimicking human thanatophoric dysplasia. Hum Mol Genet 21:5443-5455. Kishnani PS, Rockman-Greenberg C, Whyte MP, Weber T, Mhanni A, Madson K, Reeves A, Mack K, Plotkin H, Kreher N, Landy H. 2012. Hypophosphatasia: enzyme replacement therapy (Asfotase alfa) decreases TNSALP substrate accumulation and improves functional outcome in affected adolescents and adults. American College of Medical Genetics and Genomics Annual Meeting, 
Charlotte, NC, USA, March 27-31.

Klag KA, Horton WA. 2015. Advances in treatment of achondroplasia and osteoarthritis. Hum Mol Genet 25:R2-8.

Krakow D, Rimoin DL. 2010. The skeletal dysplasias. Genet Med 12(6):327-341.

Krejci P, Masri B, Fontaine V, Mekikian PB, Weis M, Prats H, Wilcox WR. 2005.

Interaction of fibroblast growth factor and C-natriuretic peptide signaling in regulation of chondrocyte proliferation and extracellular matrix homeostasis. J Cell Sci 118:5089-5100.

Laine CM, Wessman M, Toiviainen-Salo S, Kaunisto MA, Mäyränpää MK, Laine T, Pekkinen M, Kröger H, Välimäki VV, Välimäki MJ, Lehesjoki AE, Mäkitie O. 2015. A novel splice mutation in PLS3 causes X-linked early onset low-turnover osteoporosis. J Bone Miner Res 30:510-518.

Land C, Rauch F, Munns CF, Sahebjam S, Glorieux FH. 2006. Vertebral morphometry in children and adolescents with osteogenesis imperfecta: effect of intravenous pamidronate treatment. Bone 39:901-906.

Leadley RM, Lang S, Misso K, Bekkering T, Ross J, Akiyama T, Fietz M, Giugliani R, Hendriksz CJ, Hock NL, McGill J, Olaye A, Jain M, Kleijnen J. 2014. A systematic review of the prevalence of Morquio A syndrome: challenges for study reporting in rare diseases. Orphanet J Rare Dis 9:173.

Letocha AD, Cintas HL, Troendle JF, Reynolds JC, Cann CE, Chernoff EJ, Hill SC, Gerber LH, Marini JC. 2005. Controlled trial of pamidronate in children with types III and IV osteogenesis imperfecta confirms vertebral gains but not short-term functional improvement. J Bone Miner Res 20:977-986.

Lindahl K, Langdahl B, Ljunggren Ö, Kindmark A. 2014. Treatment of osteogenesis 
imperfect in adults. Eur J Endocrinol 171:R79-90.

Lowing K, Astrom E, Oscarsson KA, Söderhäll S, Eliasson AC. 2007. Effect of intravenous pamidronate therapy on everyday activities in children with osteogenesis imperfecta. Acta Paediatr 96:1180-1183.

Madson KL, Rockman-Greenberg C, Melian A, Moseley S, Odrljin T, Whyte MP; for the Study 008-10 Investigators. 2014. Asfotase alfa: long-term safety and efficacy in children with hypophosphatasia. Pediatric Academic Societies and Asian Society for Pediatric Research Joint Meeting, Vancouver, BC, Canada, May 3-6, 2014.

Matsushita M, Hasegawa S, Kitoh H, Mori K, Ohkawara B, Yasoda A, Masuda A, Ishiguro N and Ohno K. 2015. Meclozine promotes longitudinal skeletal growth in transgenicmice with achondroplasia carrying a gain-of-function mutation in the FGFR3 gene. Endocrinol 156:548-554.

Matsushita M, Kitoh H, Ohkawara B, Mishima K, Kaneko H, Ito M, Masuda A, Ishiguro $\mathrm{N}$ and Ohno K. 2013. Meclozine facilitates proliferation and differentiation of chondrocytes by attenuating abnormally activated FGFR3 signaling in achondroplasia. PLoS One 8:e81569.

Millán JL, Narisawa S, Lemire I, Loisel TP, Boileau G, Leonard P, Gramatikova S, Terkeltaub R, Camacho NP, McKee MD, Crine P, Whyte MP. 2008. Enzyme replacement therapy for murine hypophosphatasia. J Bone Miner Res 23:777787.

Miura K, Kim OH, Lee HR, Namba N, Michigami T, Yoo WJ, Choi IH, Ozono K, Cho TJ. 2014. Overgrowth syndrome associated with a gain-of-function mutation of the natriuretic peptide receptor 2 (NPR2) gene. Am J Med Genet A 164A: 156-163. 
Miura K, Namba N, Fujiwara M, Ohata Y, Ishida H, Kitaoka T, Kubota T, Hirai H, Higuchi C, Tsumaki N, Yoshikawa H, Sakai N, Michigami T, Ozono K. 2012. An overgrowth disorder associated with excessive production of CGMP due to a gain-of-function mutation of the natriuretic peptide receptor 2 gene. PLoS One 7:e42180.

Miyazawa T, Ogawa Y, Chusho H, Yasoda A, Tamura N, Komatsu Y, Pfeifer A, Hofmann F, Nakao K. 2002. Cyclic GMP-dependent protein kinase II plays a critical role in C-type natriuretic peptide-mediated endochondral ossification. Endocrinology 143:3604-3610.

Monti E, Mottes M, Fraschini P, Brunelli P, Forlino A, Venturi G, Doro F, Perlini S, Cavarzere P, Antoniazzi F. 2010. Current and emerging treatments for the management of osteogenesis imperfecta. Ther Clin Risk Manag 6:367-381.

Mornet E, Yvard A, Taillandier A, Fauvert D, Simon-Bouy B. 2011. A molecular-based estimation of the prevalence of hypophosphatasia in the European population. Ann Hum Genet 75:439-445

Mornet E. 2007. Hypophosphatasia. Orphanet J Rare Dis 2:40.

Munns CF, Rauch F, Zeitlin L, Fassier F, Glorieux FH. 2004. Delayed osteotomy but not fracture healing in pediatric osteogenesis imperfecta patients receiving pamidronate. J Bone Miner Res 19:1779-1786.

Murakami S, Balmes G, McKinney S, Zhang Z, Givol D, de Crombrugghe B. 2004. Constitutive activation of MEK1 in chondrocytes causes Stat1-independent achondroplasia-like dwarfism and rescues the Fgfr3-deficient mouse phenotype. Genes Dev 18:290-305.

Nakamura-Utsunomiya A, Okada S, Hara K, Miyagawa S, Takeda K, Fukuhara R, 
Nakata Y, Hayashidani M, Tachikawa K, Michigami T, Ozono K, Kobayashi M.

2010. Clinical characteristics of perinatal lethal hypophosphatasia: A report of 6 cases. Clin Pediatr Endocrinol 19:7-13.

Narisawa S, Frohlander N, Millan JL. 1997. Inactivation of two mouse alkaline phosphatase genes and establishment of a model of infantile hypophosphatasia. Dev Dyn 208:432-446.

Naski MC, Colvin JS, Coffin JD and Ornitz DM. 1998. Repression of hedgehog signaling and BMP4 expression in growth plate cartilage by fibroblast growth factor receptor 3. Development 125:4977-4988.

Natsheh J, Drozdinsky G, Simanovsky N, Lamdan R, Erlich O, Gorelik N, Or R, Weintraub M, Stepensky P. 2016. Improved Outcomes of Hematopoietic Stem Cell Transplantation in Patients With Infantile Malignant Osteopetrosis Using Fludarabine-Based Conditioning. Pediatr Blood Cancer 63:535-540.

Nishioka T, Tomatsu S, Gutierrez MA, Miyamoto K, Trandafirescu GG, Lopez PL, Grubb JH, Kanai R, Kobayashi H, Yamaguchi S, Gottesman GS, Cahill R, Noguchi A, Sly WS. 2006. Enhancement of drug delivery to bone: characterization of human tissue-nonspecific alkaline phosphatase tagged with an acidic oligopeptide. Mol Genet Metab 88:244-255.

Orchard PJ, Fasth AL, Le Rademacher J, He W, Boelens JJ, Horwitz EM, Al-Seraihy A, Ayas M, Bonfim CM, Boulad F, Lund T, Buchbinder DK, Kapoor N, O'Brien TA, Perez MA, Veys PA, Eapen M. 2015. Hematopoietic stem cell transplantation for infantile osteopetrosis. Blood 126:270-276.

Orimo H. 2010. The mechanism of mineralization and the role of alkaline phosphatase in health and disease. J Nippon Med Sch 77:4-12. 
Ornitz DM. 2005. FGF signaling in the developing endochondral skeleton. Cytokine Growth Factor Rev 16:205-213.

Orwoll ES, Shapiro J, Veith S, Wang Y, Lapidus J, Vanek C, Reeder JL, Keaveny TM, Lee DC, Mullins MA, Nagamani SC, Lee B. 2014. Evaluation of teriparatide treatment in adults with osteogenesis imperfecta. J Clin Invest 124:491-8.

Palomo T, Fassier F, Ouellet J, Sato A, Montpetit K, Glorieux FH, Rauch F. 2015. Intravenous Bisphosphonate Therapy of Young Children With Osteogenesis Imperfecta: Skeletal Findings During Follow Up Throughout the Growing Years. Journal of Bone and Mineral Research 30:2150-2157.

Pignolo RJ, Shore EM, and Kaplan FS. 2011. Fibrodysplasia Ossificans Progressiva: Clinical and Genetic Aspects. Orphanet J Rare Dis 6:80.

Rauch F, Plotkin H, Zeitlin L, Glorieux FH. 2003. Bone mass, size, and density in children and adolescents with osteogenesis imperfecta: effect of intravenous pamidronate therapy. J Bone Miner Res 18:610-614.

Rauchenberger R, Borges E, Thomassen-Wolf E, Rom E, Adar R, Yaniv Y, Malka M, Chumakov I, Kotzer S, Resnitzky D, Knappik A, Reiffert S, Prassler J, Jury K, Waldherr D, Bauer S, Kretzschmar T, Yayon A, Rothe C. 2003. Human combinatorial Fab library yielding specific and functional antibodies against the human fibroblast growth factor receptor 3. J Biol Chem 278:38194-38205.

Reyes C, Hitz M, Prieto-Alhambra D, Abrahamsen B. 2016. Risks and Benefits of Bisphosphonate Therapies. Journal of Cellular Biochemistry 117:20-28.

Rockman-Greenberg C, Vockley J, Harmatz P, Vallée M, Bedrosian CL, Hofmann C, Liese J. 2014. Asfotase alfa improves skeletal mineralization and respiratory function in infants and young children with hypophosphatasia: results from up to 
12 months' treatment. American College of Medical Genetics \& Genomics Annual Meeting, Nashville, TN, USA, March 25-29, 2014.

Rockman-Greenberg C. 2013. Hypophosphatasia. Pediatr Endocrinol Rev 10:380-388.

Seikaly MG, Kopanati S, Salhab N, Waber P, Patterson D, Browne R, Herring JA. 2005. Impact of alendronate on quality of life in children with osteogenesis imperfecta. J Pediatr Orthop 25:786-791.

Shaker JL, Albert C, Fritz J, Harris G. 2015. Recent developments in osteogenesis imperfecta. F1000Res 4:681.

Shore EM, Xu M, Feldman GJ, Fenstermacher DA, Cho T-J, Choi IH, Connor M, Delai P, Glaser DL, Le Merrer M, Morhart R, Rogers JG, Smith R, Triffitt JT, Urtizberea JA, Zasloff M, Brown MA, Kaplan FS. 2006. A recurrent mutation in the BMP type I receptor ACVR1 causes inherited and sporadic fibrodysplasia ossificans progressiva. Nat Genet 38:525-527.

Sinha S, Uchibe K, Usami Y, Pacifici M, Iwamoto M. Effectiveness and mode of action of a combination therapy for heterotopic ossification with a retinoid agonist and an anti-inflammatory agent. Bone. In Press.

Suda M, Ogawa Y, Tanaka K, Tamura N, Yasoda A, Takigawa T, Uehira M, Nishimoto H, Itoh H, Saito Y, Shiota K, Nakao K. 1998. Skeletal overgrowth in transgenic mice that overexpress brain natriuretic peptide. Proc Natl Acad Sci USA 95:23372342.

Sugano H, Matsumoto T, Miyake K, Watanabe A, lijima O, Migita M, Narisawa S, Millan JL, Fukunaga Y, and Shimada T. 2012. Successful Gene Therapy in Utero for Lethal Murine Hypophosphatasia. Human Gene Therapy 23:399-406.

Tadokoro M, Kanai R, Taketani T, Uchio Y, Yamaguchi S, Ohgushi H. 2009. New bone 
formation by allogeneic mesenchymal stem cell transplantation in a patient with perinatal hypophosphatasia. J Pediatr 154:924-930.

Taketani T, Kanai R, AbeM, Mishima S, TadokoroM, Katsube Y, Yuba S, Ogushi H, Fukuda S, Yamaguchi S. 2013. Therapy related Ph+ leukemia after both bone marrow and mesenchymal stem cell transplantation for hypophosphatasia. Pediatr Int 55:e52-55.

Taketani T, Oyama C, Mihara A, Tanabe Y, Abe M, Hirade T, Yamamoto S, Bo R, Kanai R, Tadenuma T, Michibata Y, Yamamoto S, Hattori M, Katsube Y, Ohnishi H, Sasao M, Oda Y, Hattori K, Yuba S, Ohgushi H, Yamaguchi S. 2015. Ex vivo expanded allogeneic mesenchymal stem cells with bone marrow transplantation improved osteogenesis in infants with severe hypophosphatasia. Cell Transplant 24:19311943.

Tomatsu S, Alméciga-Díaz CJ, Barbosa H, Montaño AM, Barrera LA, Shimada T, Yasuda E, Mackenzie WG, Mason RW, Suzuki Y, Orii KE, Orii T. 2013. Therapies of mucopolysaccharidosis IVA (Morquio A syndrome). Expert Opin Orphan Drugs $1: 805-818$.

van Dijk FS, Zillikens MC, Micha D, Riessland M, Marcelis CL, de Die-Smulders CE, Milbradt J, Franken AA, Harsevoort AJ, Lichtenbelt KD, Pruijs HE, Rubio-Gozalbo ME, Zwertbroek R, Moutaouakil Y, Egthuijsen J, Hammerschmidt M, Bijman R, Semeins CM, Bakker AD, Everts V, Klein-Nulend J, Campos-Obando N, Hofman A, te Meerman GJ, Verkerk AJ, Uitterlinden AG, Maugeri A, Sistermans EA, Waisfisz Q, Meijers-Heijboer H, Wirth B, Simon ME, Pals G. 2013. PLS3 mutations in Xlinked osteoporosis with fractures. N Engl J Med 369:1529-1536.

Vasques GA, Amano N, Docko AJ, Funari MF, Quedas EP, Nishi MY, Arnhold IJ, 
Hasegawa T, Jorge AA. 2013. Heterozygous mutations in natriuretic peptide receptor-B (NPR2) gene as a cause of short stature in patients initially classified as idiopathic shortstature. J Clin Endocrinol Metab 98:E1636-E1644.

Watson JD, Crick F. 1953. Molecular structure of nucleic acids: A structure for deoxyribose nucleic acid. Nature 171:737-738.

Waymire KG, Mahuren JD, Jaje JM, Guilarte TR, Coburn SP, MacGregor GR. 1995. Mice lacking tissue non-specific alkaline phosphatase die from seizures due to defective metabolism of vitamin B-6. Nat Genet 11:45-51.

Wendt DJ, Dvorak-Ewell M, Bullens S, Lorget F, Bell SM, Peng J, Castillo S, AoyagiScharber M, O'Neill CA, Krejci P, Wilcox WR, Rimoin DL, Bunting s. 2015. Neutral endopeptidase-resistant C-type natriuretic peptide variant represents a new therapeutic approach for treatment of fibroblast growth factor receptor 3related dwarfism. J Pharmacol Exp Ther 353:132-149.

Whyte MP, Greenberg CR, Salman NJ, Bober MB, McAlister WH, Wenkert D, Van Sickle BJ, Simmons JH, Edgar TS, Bauer ML, Hamdan MA, Bishop N, Lutz RE, McGinn M, Craig S, Moore JN, Taylor JW, Cleveland RH, Cranley WR, Lim R, Thacher TD, Mayhew JE, Downs M, Millán JL, Skrinar AM, Crine P, Landy H. 2012. Enzyme-replacement therapy in life threatening hypophosphatasia. N Engl J Med 366:904-913.

Whyte MP, Kurtzberg J, McAlister WH, Mumm S, Podgornik MN, Coburn SP, Ryan LM, Miller CR, Gottesman GS, Smith AK, Douville J, Waters-Pick B, Armstrong RD, Martin PL. 2003. Marrow cell transplantation for infantile hypophosphatasia. J Bone Miner Res 18:624-636

Whyte MP, Simmons JH, Bishop N, Lutz RE, Vallée M, Melian A, Odrljin T; for the 
Study 003-08 Investigators. 2014. Asfotase alfa: sustained efficacy and

tolerability in infants and young children with life-threatening hypophosphatasia.

Pediatric Academic Societies and Asian Society for Pediatric Research Joint

Meeting, Vancouver, BC, Canada, May 3-6, 2014.

Whyte MP. 2010. Physiological role of alkaline phosphatase explored in

hypophosphatasia. Ann N Y Acad Sci 1192:190-200.

Yamashita A, Morioka M, Kishi H, Kimura T, Yahara Y, Okada M, Fujita K, Sawai H, Ikegawa S, Tsumaki N. 2014. Statin treatment rescues FGFR3 skeletal dysplasia phenotypes. Nature 513:507-511.

Yasoda A, Komatsu Y, Chusho H, Miyazawa T, Ozasa A, Miura M, Kurihara T, Rogi T, Tanaka S, Suda M, Tamura N, Ogawa Y, Nakao K. 2004. Overexpression of CNP in chondrocytes rescues achondroplasia through a MAPK-dependent pathway. Nat Med 10:80-86.

Yasoda A, Ogawa Y, Suda M, Tamura N, Mori K, Sakuma Y, Chusho H, Shiota K, Tanaka K, Nakao K. 1998. Natriuretic peptide regulation of endochondral ossification. Evidence for possible roles of the C-type natriuretic peptide/guanylyl cyclase-B pathway. J Biol Chem 273:11695-11700.

Zasloff MA, Roche DM, Crofford U, Hahn GV, Kaplan FS. 1998. Treatment of patients who have fibrodysplasia ossificans progressiva with isotretinoin. Clin Orthop 346:121-129.

Table I. Summary of drug therapies in osteogenesis imperfecta.

\begin{tabular}{|l|c|c|}
\hline Drug therapy & Mode of action & Effects \\
\hline 1. Bisphosphonates & $\begin{array}{l}\text { Reduce number of } \\
\text { osteoclasts }\end{array}$ & $\begin{array}{l}\text { Reduce bone } \\
\text { resorption }\end{array}$ \\
\hline
\end{tabular}




\begin{tabular}{|c|c|c|}
\hline & $\begin{array}{ll} & \text { Antagonism of } \\
& \text { osteoclast activities }\end{array}$ & \\
\hline $\begin{array}{l}\text { 2. Anabolic agents } \\
\text { (e.g. Growth hormone and } \\
\text { teriparatide) }\end{array}$ & $\begin{array}{l}\text { - Stimulate bone } \\
\text { formation }\end{array}$ & $\begin{array}{ll}\text { - Increase BMD and } \\
\text { strength }\end{array}$ \\
\hline 3. Denosumab & $\begin{array}{l}\text { Monoclonal } \\
\text { antibodies that bind } \\
\text { RANKL and disrupt } \\
\text { osteoclast } \\
\text { formation, activation } \\
\text { and survival }\end{array}$ & $\begin{array}{l}\text { - } \begin{array}{l}\text { Decrease bone } \\
\text { resorption }\end{array} \\
\end{array}$ \\
\hline 4. Anti-sclerostin antibody & $\begin{array}{l}\text { - Inhibition of } \\
\text { LRP5/WnT signaling } \\
\text { pathway }\end{array}$ & $\begin{array}{l}\text { - Increase bone } \\
\text { formation }\end{array}$ \\
\hline 5. Anti-TGF- $\beta$ antibody & $\begin{array}{ll}\text { - } & \text { Inhibition of TGF- } \beta \\
& \text { signaling pathway }\end{array}$ & $\begin{array}{l}\text { - Decrease bone } \\
\text { resorption }\end{array}$ \\
\hline 6. Gene silencing & $\begin{array}{l}\text { Allele-specific gene } \\
\text { silencing by } \\
\text { inhibitory RNA } \\
\text { directed towards } \\
\text { dominant negative } \\
\text { mutations }\end{array}$ & $\begin{array}{l}\text { Reduce defective } \\
\text { protein/collagen }\end{array}$ \\
\hline
\end{tabular}

Key: BMD, bone mineral density; RANKL, Receptor activator of nuclear factor (NFkappa $\beta$ ) ligand; LRP5/WnT, low density lipoprotein receptor-related protein/ wingless-type MMTV (mouse mammary tumor virus) integration site; TGF- $\beta$, transforming growth factor- $\beta$.

\section{LEGENDS}

Figure 1. Targets for pharmacological intervention in the treatment for achondroplasia. A. P3 blocking peptide and decoy receptor; B. The CNP-mediated antagonism of downstream FGFR3 signaling; C. Downstream signal interruption of mutant FGFR3 (e.g., meclozine, statin). Diagram is modified from Klag and Horton [2015]. 
Key: FGF, fibroblast growth factor; FGFR3, fibroblast growth factor receptor 3; CNP, C-natriuretic peptide; NPR-B, natriuretic peptide receptor-B; STAT, signal transducer and activator of transcription; MAPK, mitogen-activated protein kinase.

Figure 2. Bone mineralization commences with intracellular hydroxyapatite formation within matrix vesicles. Hydroxyapatite crystals then bud from the surface of the matrix vesicle and propagate into extracellular matrix where they are elongated and finally deposited between collagen fibrils. The PPi/Pi balance is essential in bone mineralization. Tissue-nonspecific alkaline phosphatase (TNSALP) functions as ecto-enzyme that converts extracellular PPi to Pi. ALPL mutations in severe hypophosphatasia result in production of mutant TNSALP proteins that fail to migrate to the surface of cellular membrane. The lack of Pi and accumulation of PPi cause decreased and further inhibit bone mineralization. Asfotase alfa restores bone mineralization. Diagram adapted from Orimo H [2010]. Key: HA, hydroxyapatite; PPi, inorganic pyrophosphate; Pi, inorganic phosphate; ATP, adenosine triphosphate; TNSALP, tissue non-specific alkaline phosphatase; NPP1, ectonucleotide pyrophosphatase phosphodiesterase 1; ANKH, ankylosis protein. 


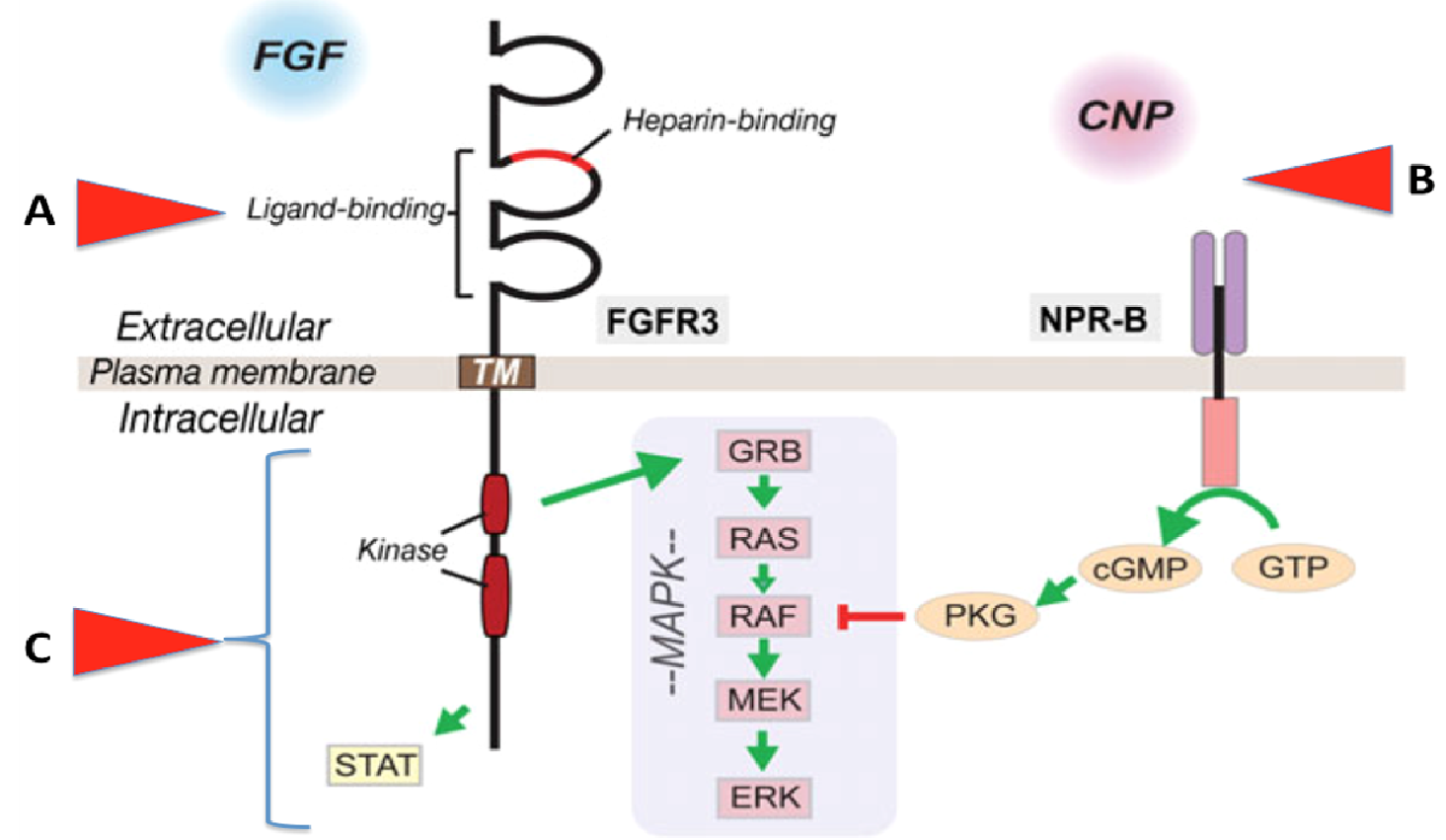

Figure 1 AJMG . 


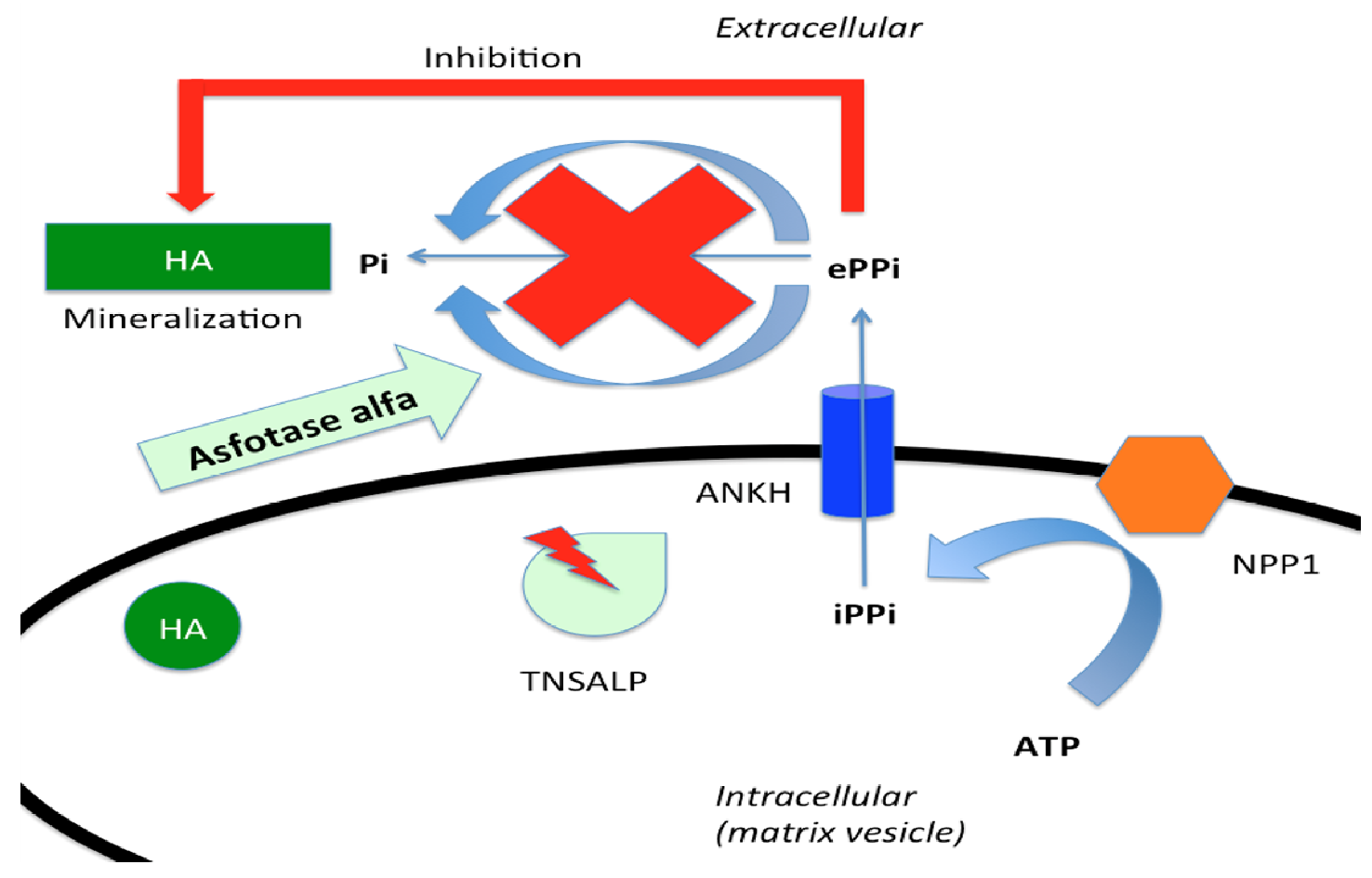

Figure 2 AJMG . 


\section{University Library}

\section{- M M I E R R A A gateway to Melbourne's research publications}

Minerva Access is the Institutional Repository of The University of Melbourne

Author/s:

Yap, $P$;Savarirayan, $R$

Title:

Emerging targeted drug therapies in skeletal dysplasias

Date:

2016-10-01

Citation:

Yap, P. \& Savarirayan, R. (2016). Emerging targeted drug therapies in skeletal dysplasias. AMERICAN JOURNAL OF MEDICAL GENETICS PART A, 170 (10), pp.2596-2604. https:// doi.org/10.1002/ajmg.a.37734.

Persistent Link:

http://hdl.handle.net/11343/291287 